\title{
In silico and in vivo analysis of $A B I 3$ and VAL2 genes during somatic embryogenesis of Coffea arabica: competence acquisition and developmental marker genes
}

\author{
Natália Chagas Freitas ${ }^{1} \cdot$ Horllys Gomes Barreto $^{2} \cdot$ Luana Ferreira Torres $^{1} \cdot$ Luciana Lima Freire $^{1}$. \\ Leonardo Augusto Zebral Rodrigues ${ }^{1} \cdot$ Leandro Eugenio Cardamone Diniz $^{3} \cdot$ Luiz Alberto Beijo $^{4}$. \\ Luciano Vilela Paiva' ${ }^{1}$ (1)
}

Received: 14 June 2018 / Accepted: 8 March 2019

(c) Springer Nature B.V. 2019

\begin{abstract}
The employment of biotechnology-based approaches such as somatic embryogenesis has been applied to several plants including Coffea sp. Despite the economic importance of this genus, few information about the role of key regulatory genes in somatic embryogenesis in coffee is available. This work provides information about $A B I 3$ and VAL2 genes performance by RT-qPCR during indirect somatic embryogenesis of Coffea arabica. To achieve this, bioinformatics analysis was performed to identify the genes of the B3 superfamily in the coffee genome. The cell suspensions lines presented similar histological and regeneration patterns, yielding of up to 6.6 embryos per $1 \mathrm{mg}$ of embryogenic aggregates at 7 months. We have identified possible orthologs for VAL2 (Cc06g00410) and $A B I 3(\mathrm{Cc} 01 \mathrm{~g} 17380)$ as well as the other members belonging to superfamily B3. The CaABI3 expression was higher in dedifferentiated competent cells for somatic embryogenesis as compared with non-embryogenic calli. Whereas the expression of VAL2 gene is more active in cotyledonary embryos and plantlets, showing its clear performance in the embryogenesis late stages. The present study suggests that CaABI3 gene could be potentially used as a biomarker for embryogenic process improvement. The good plantlets development obtained from the protocol used may be a reflection of the high expression of CaVAL2 in cotyledonary embryos and plantlets.
\end{abstract}

\section{Key message}

The activity of $C a A B I 3$ is correlated to embryogenic potential with highly expressed in embryogenic masses and expression of the VAL2 gene is increased at the end of the embryogenic process.

Keywords Embryogenic cultures · Coffee $\cdot$ RT-qPCR $\cdot$ Abscisic acid-insensitive $3 \cdot$ Viviparous1/abi3-like2

\section{Introduction}

The employment of biotechnology-based approaches such as somatic embryogenesis (SE) can effectively support breeding programs because it has a critical role at in vitro plant

Communicated by Sergey V. Dolgov.

Electronic supplementary material The online version of this article (https://doi.org/10.1007/s11240-019-01594-7) contains supplementary material, which is available to authorized users.

Luciano Vilela Paiva

luciano@dqi.ufla.br

Extended author information available on the last page of the article propagation and it is a powerful technique for synthetic seed production, germplasm conservation of elite plant or genetically modified plants generation (Ahmad et al. 2011; Guan et al. 2016; Martins et al. 2016; Singh et al. 2016). Several crops that apply genetic engineering systems use embryogenic tissue culture as a strategy for transformation process, as single epidermal cell origins for embryos might avoid chimeras (Barampuram and Zhang 2011; Normah et al. 2013). In coffee approximately $100 \%$ efficiency in genetic transformation events have been obtained through the regeneration of plants via indirect SE (Ribas et al. 2011).

Although SE is widely used, regeneration of somatic embryos can be extremely reduced when the embryogenic competence is present only in a small cellular agglomerates 
fraction, thus reducing the quality of plant material (QuirozFigueroa et al. 2006). Moreover, the empirical identification of the more suitable culture medium composition under in vitro condition may be laborious, can be also genotype dependent, and has a relation with tissue and physiological conditions of the donor plant (Loyola-Vargas et al. 1999; Golovko 2001; Ascencio-Cabral et al. 2008; Farzana et al. 2008; Simões et al. 2010; Malabadi et al. 2011; Pinto et al. 2011; Sun et al. 2011; Anandan et al. 2012; Florez et al. 2015).

Understand the mechanisms involved during the induction, maturation and somatic embryos conversion in different species will improve the development of an efficient plant regeneration method. Physiological, biochemical and molecular markers can be used to identify embryogenically competent cells which could help to improve many of tissue culture current limitations related to cultivation time, sensitivity and specificity of each culture (Cloutier et al. 1994; Jiménez 2001). Reverse-transcriptase quantitative polymerase chain reaction (RT-qPCR) analysis stands out as a reliable and efficient approach to identify key genes during SE in steps of induction and/or differentiation (Delporte et al. 2013; Silva et al. 2014). Among the genes encoding proteins that are part of the induction and development of the embryos are those belonging to the ABI3 and HSI/VAL family of the B3 domains (Suzuki and McCarty 2008). In Arabidopsis thaliana the ABI3 family comprises the $A F L$ genes-ABSCISIC ACID-INSENSITIVE 3 (ABI3), FUSCA 3 (FUS3) and LEAFY COTYLEDON 2 (LEC2) - and HSI family is represented by the classical three members- $H I G H$ LEVEL EXPRESSION OF SUGAR-INDUCIBLE GENE 2 (HSI2), HSI2-Like1 (HSL1) and HSI2-Like2 (HSL2). This family is also known as VAL group-VIVIPAROUSI/ABI3Like1 (VAL1), VIVIPAROUS1/ABI3-Like2 (VAL2) and VIVIPAROUSI/ABI3-Like3 (VAL3) (Tsukagoshi 2005; Suzuki et al. 2007; Tsukagoshi et al. 2007; Swaminathan et al. 2008).

Several studies have shown correlations between $A F L$ genes expression with the embryogenic response induction in somatic tissues (Stone et al. 2001; Gaj et al. 2005; Kikuchi et al. 2006; Ledwoń and Gaj 2009; Zhang et al. 2014). There is no information regarding the contribution of $V A L$ genes to the regulation of somatic embryogenesis in plants. It is known only that in zygotic embryogenesis these genes together with other transcription factors are repressors of the $A F L$ genes and inhibition is required during germination for the growth of the seedlings (Jia et al. 2013; Sharma et al. 2013). Our study proposes the identification and the expression analysis of one representative gene of each family$A B I 3$ and VAL2 - to ascertain the regulatory effect of these genes during SE in Coffea arabica. Despite the agronomic importance worldwide, only few genes with a direct role in $\mathrm{SE}$ in coffee tissue culture are known.
To better understand the genomic factors involved in key regulatory genes in somatic embryogenesis and development of more efficient regeneration protocols in coffee, we characterized the expression patterns of $A B I 3$ and VAL2 during the process of indirect SE in $C$. arabica. The work also involves the global identification in silico of the B3 superfamily as well as characterization of embryogenic potential by histological analysis and regeneration of plant material.

\section{Materials and methods}

\section{Plant material and establishment of SE}

Embryogenic calli, non-embryogenic calli, embryogenic cell suspension cultures, somatic embryos at different stages of development and coffee plantlets constituted the plant materials used in the experiment. Embryogenic and non-embryogenic calli were induced in five months from young leaves of mother plants of $C$. arabica cultivar 'Catuaí Amarelo IAC 62' using PM and SM media, according to the protocol described by Teixeira et al. (2004).

Embryogenic cell suspensions were established at an inoculum density of $10 \mathrm{~g} \mathrm{~L}^{-1}$ (Zamarripa et al. 1991) by $200 \mathrm{mg}$ of embryogenic calli inoculation to $125-\mathrm{mL}$ Erlenmeyer flasks containing $20 \mathrm{~mL}$ of liquid multiplication medium CP (Van Boxtel and Berthouly 1996) but modified to increase the concentration of myo-inositol to $100 \mathrm{mg} \mathrm{L}^{-1}$ and with addition $500 \mathrm{mg} \mathrm{L}^{-1}$ of citric acid. The flasks were maintained in an orbital shaker at $100 \mathrm{rpm}$ at $25^{\circ} \mathrm{C} \pm 2{ }^{\circ} \mathrm{C}$, in the dark. The cultures were subcultured every 15 days with complete medium renovation. After 2 months, the embryogenic cell suspensions were used to start the experiment.

To analyze the time multiplication effect of cell suspension culture on the regeneration of somatic embryos, $40 \mathrm{mg}$ sectors of embryogenic aggregate were inoculated in 250$\mathrm{mL}$ Erlenmeyer flasks containing $40 \mathrm{~mL}$ of $\mathrm{RR}$ medium (Maciel et al. 2016) modified with $0.5 \mathrm{mg} \mathrm{L}^{-1}$ of naphthaleneacetic acid (NAA). The flasks were maintained in an orbital shaker at $100 \mathrm{rpm}$ at $25{ }^{\circ} \mathrm{C} \pm 2{ }^{\circ} \mathrm{C}$, in the dark during 75 days. After this period, the total number of embryos per sector was estimated with a stereoscopic microscope (EasyPath). A completely randomized design with two cell lines of embryogenic cell suspensions was used, each line consisted of three biological replicates with $40 \mathrm{mg}$ of embryogenic aggregates for repetition and six culture times $(2,3,4$, 5, 6 and 7 months). The data were processed by applying the statistics software package R (R Development Core Team 2008), and polynomial regression analysis was conducted.

The embryos were transferred to Petri dishes with the MGM solid medium as reported by Teixeira et al. (2004) with modification, for the absence of indoleacetic acid (IAA) for maturation and germination, in light room with a $12 \mathrm{~h}$ 
photoperiod. The plantlets were maintained in MS medium with addition of $1 \mathrm{~g} \mathrm{~L}^{-1}$ of activated charcoal and $2.4 \mathrm{~g} \mathrm{~L}^{-1}$ Phytagel@ (Sigma, St. Louis, USA).

\section{Histological characterization}

Samples of embryogenic cell suspension cultures (two cell lines with diferent culture times: 2, 3, 4, 5, 6 and 7 months), were fixed with $\mathrm{FAA}_{70}(10 \%$ formaldehyde $+5 \%$ acetic acid $+70 \%$ ethanol, v/v) for $48 \mathrm{~h}$ at room temperature, dehydrated in a graded series of 60, 70, 80, 90 and 100\% ethanol. The samples were embedded in epoxy resin (Historesin ${ }^{\circledR}$ Leica) according to manufacturer's protocol. The blocks were sectioned into $2 \mu \mathrm{m}$ slices using manual rotary microtome (Easypath EP-31-20091), stained with 0.05\% toluidine blue (O'Brien et al. 1964) and observed under a light microscope (Zeiss, Axio Scope). The cell diameters was measured using AxioVision 4.8 capture system.

\section{Bioinformatics analyses}

Among the existing coffee species, only Coffea canephora has the fully sequenced genome available for genomics studies of the coffee community, and for this reason, the characterization of the B3 family was performed only in the $C$. canephora genome. Coffee proteins containing B3 domains were obtained from the Coffee Genome Hub (http://coffe e-genome.org/) by BLASTP using all B3 proteins of Arabidopsis as a query (e-value cut off $1 \mathrm{e}^{-5}$ ) and all identified proteins were analyzed for the presence of the B3 domain using conserved domains database (https://www.ncbi.nlm. nih.gov/cdd/). Multiple alignments with complete sequences or domains were conducted using the CLUSTALW program (Thompson et al. 1994) using default parameters and then manually revised. Phylogenetic trees were constructed using the neighbor-joining method (Saitou and Nei 1987) and p-distance on the Mega 7 program (Kumar et al. 2016) using the neighbor-joining algorithm with the Poisson correction distance and the pairwise deletion. The bootstrap values represent 1000 replicates (Sitnikova et al. 1995).

For in silico analysis of gene expression, were selected sequences at the Coffee Genome Hub belonging to ABI3 and VAL family (Accession Cc06g00410, Cc01g15330, Cc02g12530, Cc05g12680, Cc07g01190 and Cc01g17380 for genes; Accession GSCOCP00023217001, GSCOCP00016576001, GSCOCP00029271001, GSCOCP00021159001, GSCOCP00019208001 and GSCOCP00016331001 for proteins). These sequences were applied in a new search using the coffee expressed sequence tag (EST) database (CAFEST) (Vieira et al. 2006). The Gene Project interface (http://www.lge.ibi.unicamp.br/cafe/) was used to search for reads by TBLASTX and TBLASTN. The frequencies of reads from each EST-contig and singlet in the
CAFEST libraries were calculated, with subsequent normalization of the data. Normalization consisted of multiplying the frequency of each read by the ratio between the total number of reads from all libraries and the total number of reads the library where it was expressed.

\section{Relative real-time PCR}

Based on the sequences obtained at the in silico analysis, primers for VAL2 and $A B I 3$ genes were designed for RTqPCR using the Invitrogen $®$ OligoPerfect Designer (Life Technologies) tool. For the assays, total RNA was extracted from embryogenic calli, embryogenic cell suspension with different culture times and globular embryos using Macherey Nagel (Düren, Germany) NucleoSpin $®$ kits, and from non-embryogenic calli, heart/torpedo embryos, cotyledonary embryos and plantlets using Invitrogen ${ }^{\mathrm{TM}}$ (Life Technologies, Carlsbad, CA, USA) Concert ${ }^{\mathrm{TM}}$ Plant RNA reagent. Each sample comprised three biological replicates. For embryogenic and non-embryogenic calli: each repetition encompassed a set of ten calli obtained from diferent leaf explants; for the two cell lines of embryogenic cell suspensions with diferent culture times (2, 3, 4, 5, 6 and 7 months): each repetition consisted of $200 \mathrm{mg}$ of cell agglomerates for each cell line; for somatic embryos at diferent stages of development: each repetition included 275 globular embryos, 25 cordiform/torpedo embryos and 25 cotyledonary embryos; for cofee plantlets: each repetition included 25 plantlets. RNA extracts were treated with Ambion ${ }^{\circledR}$ (Life Technologies) Turbo DNA-free kit reagents in order to remove any contaminating genomic DNA. The quantity and purity of total RNA was assessed with an ND-1000 spectrophotometer (NanoDrop Technologies, Wilmington, NC, USA), while quality and integrity were verified using an Agilent 2100 Bioanalyzer (Agilent Technologies, Santa Clara, CA, USA) to ensure a RNA integrity number $(\mathrm{RIN}) \geq 7.0$. The synthesis of cDNA from $1000 \mathrm{ng}$ aliquots of RNA was carried out using Applied Biosystems (Life Technologies) High-Capacity cDNA Reverse Transcription kits according to the recommendations of the manufacturer.

RT-qPCR analyses were performed using an Applied Biosystems 7500 Real-Time PCR system with a reaction mix containing SYBR $®$ Green PCR Master Mix 2X (Applied Biosystems), $10 \mathrm{ng}$ of cDNA, optimized concentrations of primers (see Online Resource 1) and RNase-free water to a total volume of $10 \mu \mathrm{L}$. Amplification conditions involved an initial activation at $95^{\circ} \mathrm{C}$ for $10 \mathrm{~min}$ and 40 cycles of denaturation at $95{ }^{\circ} \mathrm{C}$ for $15 \mathrm{~s}$ and combined annealing at $60^{\circ} \mathrm{C}$ for $1 \mathrm{~min}$. All qPCR assays were carried out in technical and biological triplicate. The specificity of each pair of primers was verified by analysis of the dissociation (melting) curves. The expression data were normalized with reference genes 
$24 S$ and $P P 2 A$ (Freitas et al. 2017) and relatively quantified by applying Pfaffl formula (Pfaffl et al. 2001).

\section{Results}

\section{Regeneration and development of the somatic embryos}

The embryogenic calli selected in this study had intense yellow coloration, granular texture and high friability, whereas the non-embryogenic calli had high compaction and brown coloration (Fig. 1a). Cell suspensions were initialized from EC culture in liquid medium (Fig. 1b) being observed the cellular agglomerates darkening over time (Fig. 1c). The regeneration process of somatic embryos from cell suspensions was successfully obtained using experimental media and conditions described by others authors (Zamarripa et al. 1991; Van Boxtel and Berthouly 1996; Teixeira et al. 2004; Maciel et al. 2016). After 75 days on RR medium culture, the embryos formed with similar developmental stages were transferred to MGM medium (Fig. 1d, e), and left for more 60-days period, where the embryos presented a start and/or complete cotyledons formation (Fig. 1f). The embryos were submitted to germination process in MGM medium under light condition and after around 30 days the cotyledonary embryos showed development of the radicle, evidencing the conversion of somatic embryos to plantlets (Fig. 1g).

According to variance analysis (ANOVA), there was significant differences in the somatic embryos regeneration only considering the culture times $(\mathrm{p}=0.00)$ (data not shown). In both cell lines (L1 and L2) an increase in embryo regeneration was observed within the evaluated period (2-7 months). The two suspension cell lines presented an adjustment to the linear regression model regarding the regeneration rate in somatic embryos as a function of the culture time. At 2 months of culture L1 and $\mathrm{L} 2$ presented regeneration rate equivalent to 3.8 and 4.8 embryos per $1 \mathrm{mg}$ of embryogenic aggregates, respectively. The highest time measured, 7 months, promoted the additional formation of 6.6 embryos in both lines (Fig. 2).

The histological sections from embryogenic cell suspensions L1 and L2 showed the presence of proembryogenic and non-embryogenic masses in all months of evaluation (2, 3, 4, 5, 6 and 7 months) (Fig. 3). Nonembryogenic masses presented cells with $15-50 \mu \mathrm{m}$ in length, highly vacuolated, with irregular shapes and cell walls of $1.8 \mu \mathrm{m}$. Proembryogenic masses has meristematic regions with small cells ( $8-14 \mu \mathrm{m}$ in diameter), isodiametric, with dense cytoplasm, cell walls of $0.4 \mu \mathrm{m}$, voluminous nucleus with clearly evident nucleoli.
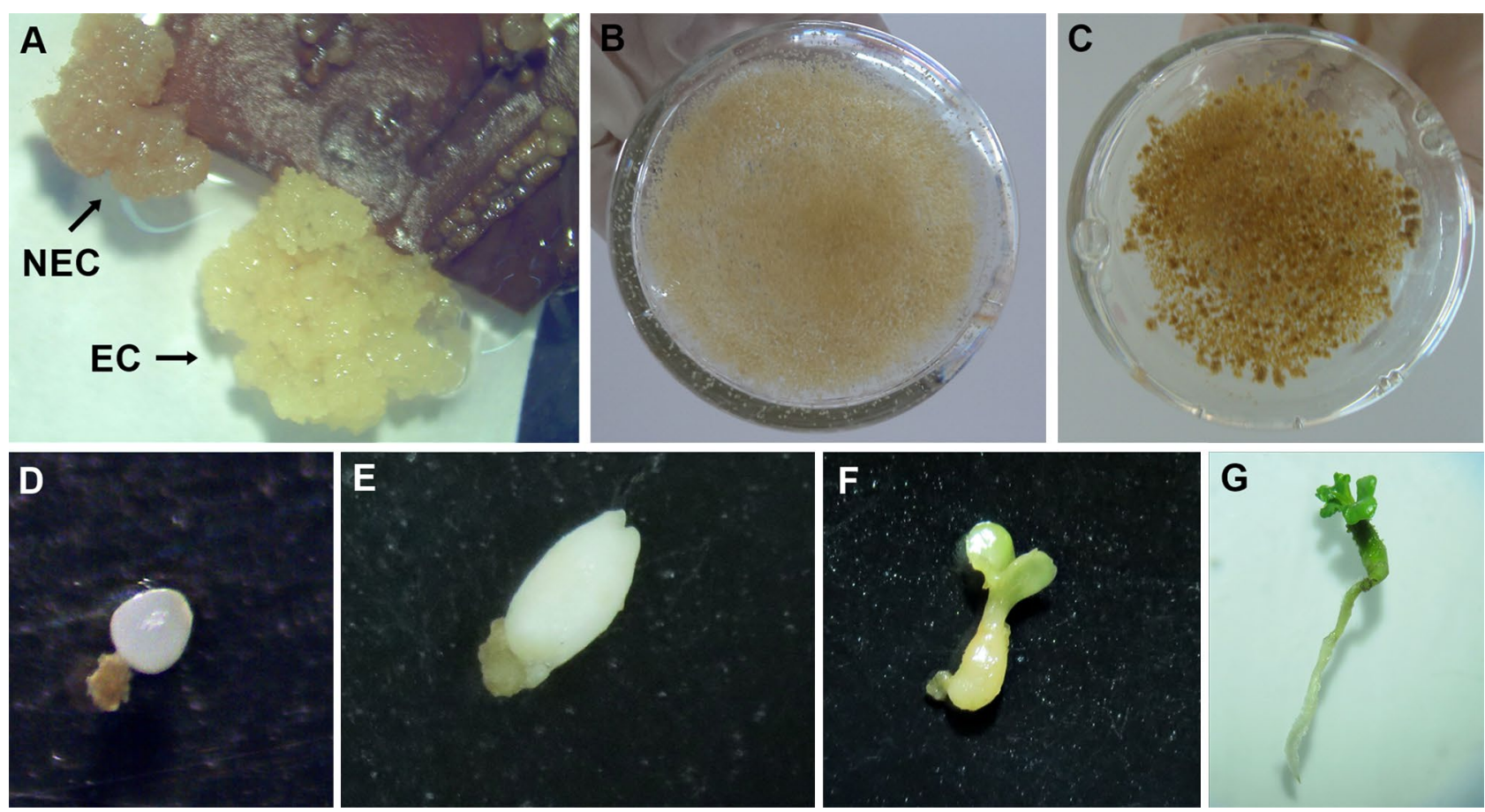

Fig. 1 Development of the somatic embryogenesis process in $C$. arabica L. a Embryogenic (EC) and non-embryogenic calli (NEC). b Embryogenic cell suspensions with 2-months culture time. c
Embryogenic cell suspensions with 7-months culture time. d Globular embryo. e Cordiform/torpedo embryo. f Cotyledonary embryo. g Plantlets 
Fig. 2 Frequency of somatic embryogenesis. Regeneration rate per $1 \mathrm{mg}$ of embryogenic aggregates in two lines (L1 and L2) of cell suspensions in $C$. arabica $\mathrm{L}$.


\section{Identification and classification of the B3 superfamily in Coffea canephora}

Romanel et al. (2009) identified 87 B3 proteins in the Arabidopsis genome using the TAIR annotation (https:// www.arabidopsis.org/) and classified them into the five known families: ARF (23 loci), VAL (3 loci), ABI3 (3 loci), RAV (13 loci) and REM (45 loci). We used these proteins to perform the BASTP in Coffee Genome Hub (http://coffee-genome.org/) and obtained 162 amino acid sequences with significant similarity (e-value $>10^{-5}$ ). After confirmation of the presence of the B3 domain by conserved domains database (https://www.ncbi.nlm.nih. gov/cdd/), we found $69 \mathrm{~B} 3$ proteins in the C. canephora genome (Online Resource 3). Phylogenetic analysis of the B3 superfamily in coffee genome comparative with Arabidopsis showed that this species possesses the same typical families with different number of members: ARF (18 loci),
VAL (4 loci), ABI3 (2 loci), RAV (4 loci) ARF and REM (41 loci) (Fig. 4).

The $\mathrm{Cc} 06 \mathrm{~g} 00410$ protein sequence presented appreciable identity to B3 domain of the VAL2 protein from Arabidopsis thaliana (92\%) (Online Resource 3A). In addition to the B3 domain, VAL2 proteins contain $\mathrm{CW}$ zinc finger domain, also present in Cc06g00410 but with low level of conservation (Online Resource 3A). The protein sequence of Cc01g17380 corresponded to similarity of $92 \%$ to B3 domain of the ABI3 protein from Arabidopsis (Online Resource 3B). The two proteins of coffee exhibit larger size compared to Arabidopsis: $\mathrm{Cc} 06 \mathrm{~g} 00410$ (852 aa) versus AtVAL2 (780 aa) and Cc01g1738 (995 aa) versus AtABI3 (720 aa).

\section{In silico expression analysis}

The CAFEST database search resulted in obtaining three EST-contigs and nine singlets with significant similarity 



Fig. 3 Histological dissection of the embryogenic cell suspensions lines of $C$. arabica L. in six culture times. a 2 months. b 3 months. c 4 months. d 5 months. e 6 months. 7 months. PEM Proembryogenic masses, $N E M$ non-embryogenic masses

$\left(\right.$ e-value $\left.<10^{-4}\right)$ to ABI3 and VAL family genes. EST-contig 1, singlets 1,2 and 3 showed similarity to Cc06g00410 (CcVAL2) with in silico expression in the libraries of EM1, SI3 (germinating seeds), LV4, LV5 (young leaves from orthotropic branch), EA1 IA1, IA2 (embryogenic calli) and CA1, IC1, PC1 (non-embryogenic calli with and without 2,4 D). EST-contigs 2, 3 and singlet 5 sequences similar to the Cc06g06260 (CcVAL1) were identified in FB1, FB2, FB4 (flower buds in different developmental stages), LV4, LV5 (young leaves from orthotropic branch) and SH2 (water deficit stresses field plants). In singlets 4 and 9 with similarity to $\mathrm{Cc} 07 \mathrm{~g} 01190$ (CcFUS3) showed expression for libraries of FR4 (fruits from C. racemosa) and EM1, SI3 (germinating seeds). Finally, in singlets 7 and 9 similar to Cc01g17380 $(C c A B I 3)$ with exclusive expression only detected in EC1 (embryogenic calli from $C$. canephora). The expression profiles of all the EST-contigs and singlets evaluated are shown in Fig. 5.

\section{Expression analysis of $V A L 2$ and $A B I 3$ genes during $\mathrm{SE}$ in $\mathrm{C}$. arabica}

Based on the bioinformatic analysis we identify potential somatic embryogenesis-related genes in coffee. Primers were designed for two sequences: (1) $\mathrm{Cc} 06 \mathrm{~g} 00410$ potential ortholog of VAL2 and (2) Cc01g17380 potential ortholog of $A B I 3$. To ensure specificity of the primers it was necessary to avoid regions of homology of the genic family while designing primers. The RT-qPCR was used to quantify the abundance of VAL2 and $A B I 3$ transcripts at different developmental stages of $C$. arabica SE. As indicated in Fig. 6 the expression profiles of two genes during indirect SE were dissimilar. In the case of VAL2, the highest expression was found in the embryogenic stages of cotyledonary and plantlets, while in non-embryogenic calli, it was reduced. The expression of $A B I 3$ was almost undetectable in the non-embryogenic calli, heart/torpedo and cotyledonary embryos, yet the highest levels were found in embryogenic cell suspension ( 2 months) and plantlets. Additionally, $C a A B I 3$ expression was much higher in embryogenic calli and embryogenic cell suspension at all culture ages (2-7 months) as compared to non-embryonic calli, corresponding to 122 up to 522 times more transcripts.

\section{Discussion}

The cultivar 'Catuaí Amarelo IAC 62' used in our study has responded successfully to the induction of embryogenic calli in PM and SM media established by Teixeira et al. (2004). However, the embryogenic sectors multiplication as well as regeneration and maturation of somatic embryos to plantlets conversion was only possible by adapting protocols (Zamarripa et al. 1991; Van Boxtel and Berthouly 1996; Teixeira et al. 2004; Maciel et al. 2016). It is well known that the genotype can influence tissue culture, in the case of somatic embryogenesis the formation of embryogenic sectors can be altered depending on the cultivar used (Quiroz-Figueroa 


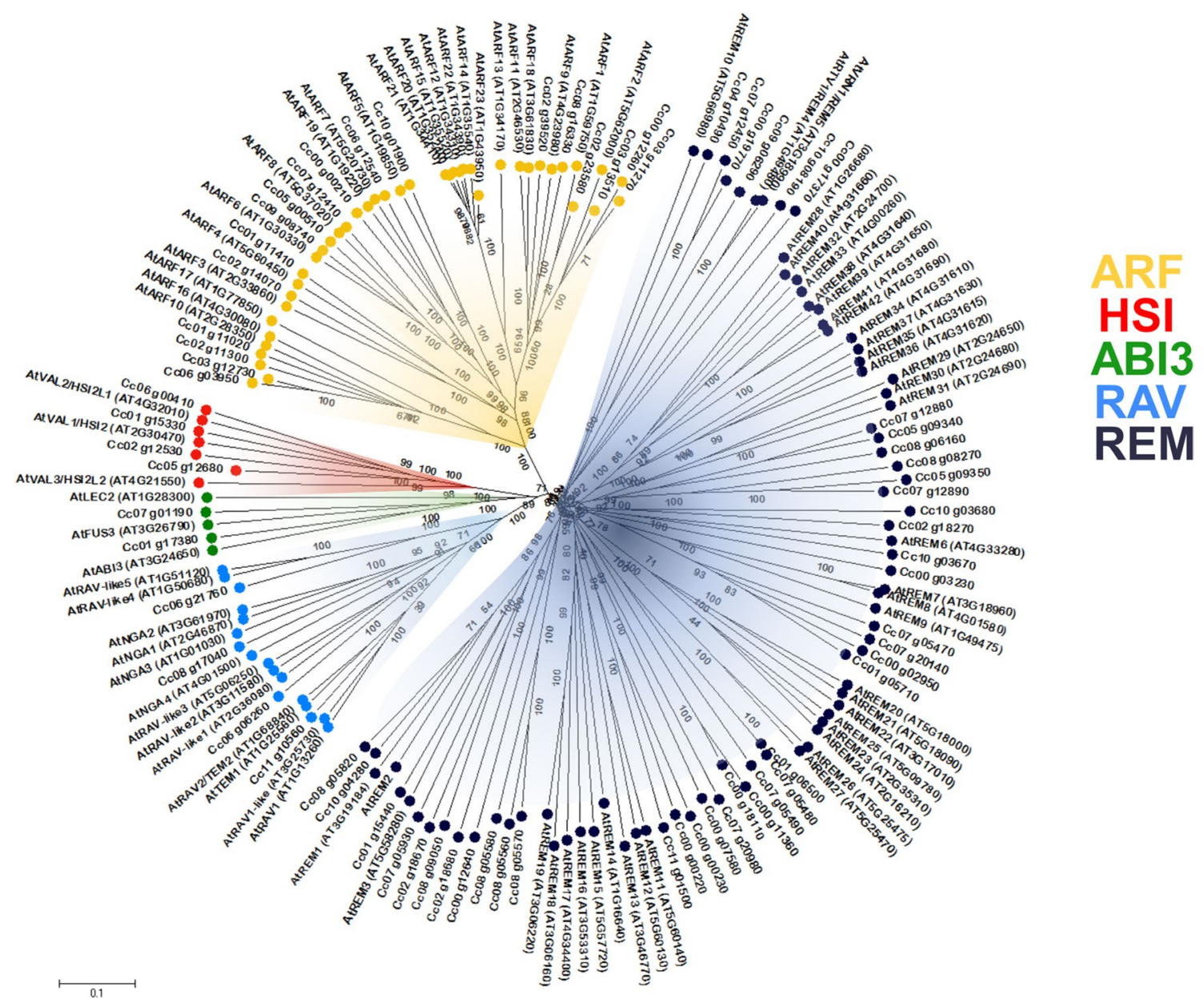

Fig. 4 Phylogenetic tree with deduced protein sequences of the B3 domain from Arabidopsis thaliana (At) and Coffea canephora (Cc). The similarity dendrogram was constructed by the neighbor-joining method and significance of each node was tested using 1000 bootstrap replicates

et al. 2002; Teixeira et al. 2004; Gatica et al. 2007; Rezende et al. 2011; Sané et al. 2012; Beena et al. 2014; Verma et al. 2016). Too many different protocols exist and cultivars display distinct outcomes to the same protocol in coffee (Campos et al. 2017). Obtaining a functional protocol for the cultivar 'Catuaí Amarelo IAC 62' is of a great importance for biotechnological applications, as this cultivar stands out as one of the most cultivated in Brazil, main coffee producer country, because of high productivity, vigor and grain quality (Carvalho 2007).

\section{Age of embryogenic cell suspensions influences regeneration}

It is possible to show that embryogenic cell suspensions can be cultured for a long time in liquid medium (7 months). The rates of regenerated embryos obtained were high-efficiency, the embryogenic cell suspensions produced up to 6.6 globular embryos per $1 \mathrm{mg}$ of calli, higher than the value recently reported by Maciel et al. (2016) with 4 embryos per $1 \mathrm{mg}$ of calli. Moreover, we found positive correlation between embryogenic sector aging and regenerative capacity. Unlike C. arabica L. cell suspensions, it has been reported that the regenerative capacity of embryogenic sectors decreased with calli aging in species such as Triticum aestivum L. (Raja et al. 2009) and Citrus jambhiri Lush (Savita et al. 2011). In addition to the increase in coffee regeneration rate, the age of the embryogenic calli cultivation also influences the achievement of greater genetic transformation efficiencies via Agrobaterium tumefaciens. While calli cultivation over the period of 7-9 months yields efficiency was close to $100 \%$ of transformed events, the 1-month culture efficiency was five times lower (Ribas et al. 2011). Therefore, long-term embryogenic sector studies becomes greatly important in order to lead to more efficient protocols. 


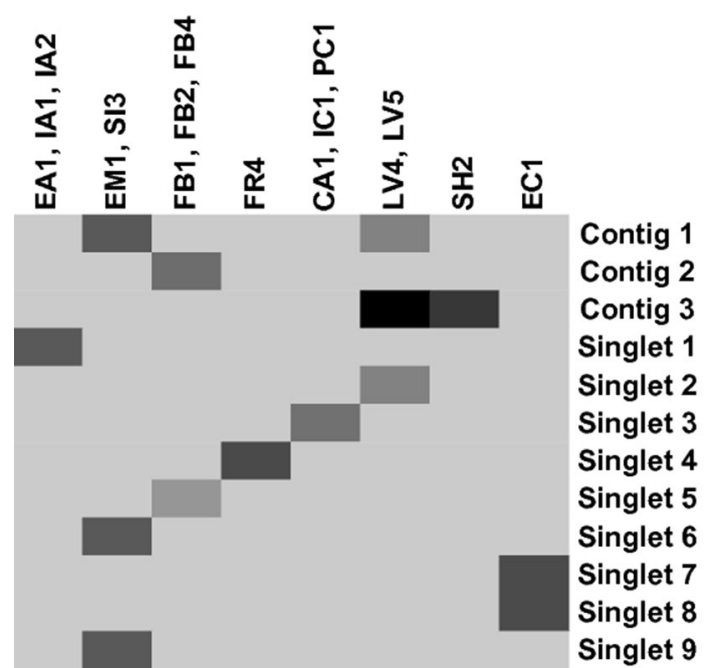

Fig. 5 Heat map of EST-contigs and singlets expression levels homologous $\mathrm{ABI} 3$ and VAL family sequences in the coffee libraries. The normalized number of reads for the transcripts in each library is represented by grayscale, where the darker the shade, the higher is the expression. Coffee libraries: EA1, IA1, IA2: embryogenic calli; EM1, SI3: germinating seeds (whole seeds and zygotic embryos); FB1, FB2, FB4: flower buds in different developmental stages; FR4: fruits from Coffea racemosa; CA1, IC1, PC1: non-embryogenic calli with and without 2,4 D; LV4, LV5: young leaves from orthotropic branch; SH2: water deficit stresses field plants (pool of tissues); EC1: embryogenic calli from Coffea canephora

\section{Histological characterization during embryogenic cell suspensions subculture}

The elucidation the origin and development of coffee somatic embryos was first described by Quiroz-Figueroa et al. (2002). Distinction between embryogenic and nonembryogenic callus is important factor to improve protocols

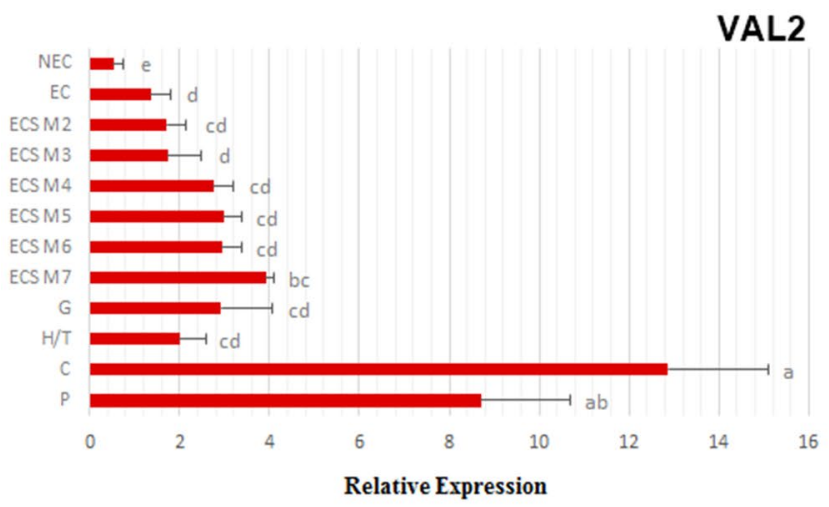

Fig. 6 Gene expression profiles during embryogenic induction and development of the somatic embryos in $C$. arabica. Relative expression of $A B I 3$ and $V A L 2$ were normalized with reference genes $P P 2 A$ and $24 S$. Different letters in columns represent the statistical significance of mean differences at a given time according to the Student's for induction and regeneration of somatic embryos in vitro (Ribas et al. 2011; Silva et al. 2014, 2015; Bartos et al. 2018). Embryogenic cell suspensions can simultaneously present proembryogenic and non-embryogenic masses (Mazarei et al. 2011; Torres et al. 2015), as it was also observed in both lines evaluated in our study at all cultivation times. It is believed that this type of heterogeneity material can affect cell suspensions viability, since non-embryogenic cells have higher rates of cell division and, therefore, faster growth (Ribas et al. 2011). Interestingly, it was observed that the non-embryogenic masses did not increase considerably with age (Fig. 3) and also did not negatively influence the somatic embryos regeneration.

The correlation of plant material with the somatic embryos potential regeneration exceeds cellular morphological typing. The somatic embryogenesis induction is related to biochemical and physiological modifications (Abbasi et al. 2016), with changes in the explants gene expression pattern and in the competent cells reprogramming that will be involved in the embryogenic process (Karami et al. 2009). Among the genes characterized in Coffea sp., emphasis has been given to the expression of SERK (Somatic Embryogenesis Receptor-Like Kinase), BBM (Baby Boom), WOX4 (Wuschel-Related Homeobox4) and LEC1 (LEAFY COTYLEDON1) genes (Nic-Can et al. 2013; Silva et al. 2014, 2015; Torres et al. 2015). Most of our knowledge about molecular regulation during somatic embryogenesis has been derived from others species such as Arabidopsis, while our knowledge about mechanisms that promote gene expression regulation of embryo development in coffee is limited. Furthermore, few studies have integrated the rate of regeneration of somatic embryos with expression profiles and morphological changes involved in SE induction, as has been reported here. 


\section{Phylogenetic studies}

The B3 gene family has been partially identified and/or characterized at the functional level in some plant species but not in coffee. Phylogenetic tree represent five subfamilies belonging to B3 family: ARF, RAV, REM, VAL and ABI3. These subfamilies were perfectly distributed in five clades. The majority of B3 domain proteins of coffee grouped the REM proteins, the high number of members may have undergone extensive gene duplication events (Romanel et al. 2009). On the other hand, RAV subfamily had the lowest number of members when compared with Arabidopsis. Transcription factors of the RAV subfamily members are involved mainly in flowering and plant development process, however, they can also respond to pathogen infections and abiotic stresses $(\mathrm{Hu}$ et al. 2004; Castillejo and Pelaz 2008; Zhao et al. 2008; Matías-Hernández et al. 2014).

ARF subfamily are the most studied of the B3 family genes, with functional information related to jasmonic acid production, ethylene and auxin signaling (Nagpal et al. 2005; Li et al. 2016; Jonsson et al. 2017; Wójcikowska and Gaj 2017). In Arabidopsis, the ARF5, ARF6, ARF10 and $A R F 16$ showed up-regulation during induction of SE, while $A R F 8$ and $A R F 17$ presented activity in embryos formation and development (Wójcikowska and Gaj 2017). Among the 18 coffee sequences grouped in the ARF subfamily clade we identified possible orthologs for $A R F 5$ (Cc10g01900), ARF6 (Cc09g08740 and $\mathrm{Cc} 05 \mathrm{~g} 00510)$ and ARF8 (Cc07g12410).

In most species, $\mathrm{ABI} 3$ subfamily is represented by $A F L$ genes: $A B I 3, F U S 3$ and $L E C 2$. However, the $C$. canephora genome has only two members ( $A B I 3$ and FUS3). A LEC2 ortholog could not be identified in C. canephora as well as in Solanum lycopersicum genome (Carbonero et al. 2017). The extensive roles of the $A F L \mathrm{~B} 3$ genes are related to several aspects of embryogenesis, including the maturation phase (Swaminathan et al. 2008; Radoeva and Weijers 2014). In our analysis, we found four amino acids sequences grouped into the VAL clade. Reports indicate that VAL1 and VAL2 genes have a role in the repression of $A F L$ genes during germination, although they are also expressed during seed maturation program (Swaminathan et al. 2008; Jia et al. 2013; Sharma et al. 2013; Schneider et al. 2016).

With in silico expression profile support, we identified ESTs with similarity to VAL2 and $A B I 3$ of $C$. canephora that showed expression in the embryogenic calli. Therefore, $C c V A L 2$ and $C C A B I 3$ are potential somatic embryogenesisrelated genes. These genes were then selected to be analysed by RT-qPCR in samples comprising embryogenic and nonembryogenic calli, embryogenic cell suspensions with diferent culture times, somatic embryos at diferent developmental stages and plantlets of the $C$. arabica.
$C a A B I 3$ is highly expressed in embryogenic masses

The $C a A B I 3$ expression was higher in embryogenic calli and embryogenic cell suspension, as compared to non-embryogenic calli, suggesting that the $C a A B I 3$ activity is correlated with embryogenic potential in coffee. It was reported that $A B I 3$ transcription factor seemed to act in controlling embryonic gene expression and seed sensitivity to abscisic acid (ABA) in Arabidopsis (Nakashima et al. 2006). Differential expression of the $A B I 3$ gene was also observed in embryogenic cultures of carrot (Shiota et al. 1998) and Arabidopsis (Ikeda-Iwai et al. 2002, 2003). However, the expression profiles of the VPI gene (orthologous to ABI3 from Arabidopsis) analyzed in banana (Musa spp.) and rye (Secale cereale L.) did not show similar patterns. In banana, the gene exhibited high expression in both embryogenic and nonembryogenic cell suspensions, and the samples presented up to 60,000 more transcripts when compared to the control explant (Shivani et al. 2017). In rye the expression level of $S c V P 1$ was basal in the analyzed tissues (leaves, zygotic embryos and calli), except for the callus of non-embryogenic line collected after 4 weeks of culture in induction medium (presented 16 times more transcripts than the embryogenic line) (Gruszczyńska and Rakoczy-Trojanowska 2011).

Moreover, high expression of $A B I 3$ at all times of embryogenic cell suspension in conjunction with somatic embryos regeneration showed the maintenance of high embryogenic competence over the period of time studied. Unlike other reports that suggest culture age decreases embryogenic competence (Ikeda-Iwai et al. 2002; Raja et al. 2009; Savita et al. 2011; Torres et al. 2015), our results show that the high proliferation rate of embryogenic cell suspension does not lead to embryogenic competence decrease because cell suspension lines with 7 months cultive presented the highest regeneration rates. In addition, the expression pattern of the gene $C a A B I 3$ could be even higher for the ECS in every analysed times (Fig. 6) if the cells were homogeneous, which it is not the case, since the ECS was heterogeneous and not composed only by proembryogenic masses (Fig. 3 ).

The $C a A B I 3$ gene exhibited high expression in the initial embryo formation (globular stage), which inferred that gene played key roles during the coffee embryogenesis initiation. Similar pattern was observed in SERK expression - molecular marker of competent cells-in Passiflora edulis (Rocha et al. 2016), Ananas comosus (Ma et al. 2014) and Cyclamen persicum (Savona et al. 2012). Therefore, we suggest that $A B I 3$ gene may be also used to identify cell competency for SE process in C. arabica. Similarly, study the CaSERK revealed similar gene expression patterns for NEC, EC and ECS in C. arabica (Silva et al. 2014). We postulate that $C a A B I 3$ and $C a S E R K$ can be served as promising molecular markers for the embryogenic cells in the species. However, for to increase reliability, it is crucial that the gene 
marker is highly expressed at that particular stage of SE (Mahdavi-Darvari et al. 2015). Hence, the $C a A B I 3$ gene may be more appropriate because it presents a greater difference of transcripts in relation to verified with CaSERK. The $A B I 3$ gene encodes a transcription factor functioning in the ABA signaling pathway (Gao et al. 2013). During the late stage of zygotic embryogenesis, it is observed the ABA peak level, when the embryos start to acquire desiccation tolerance, decreases in water content and become dormant seeds (Ikeda et al. 2006). In contrast, the expression of $C a A B I 3$ was hardly observed in the heart/torpedo and cotyledonary stage this possibly occurred because somatic embryos do not have the genetic programming for dormancy and do not accumulate ABA. In fact, many reports observed that level of endogenous ABA in the somatic embryos is extremely low (Kamada and Harada 1979; Gawronska et al. 2000; Fraga et al. 2016; Maślanka and Janowiak 2016).

Interestingly, the highest levels of $A B I 3$ transcripts were observed in plantlets. We hypothesize that the CaABI3 is expressed before lateral root development. Previous studies found that ABA may integrate other hormonal signaling pathways, for instance, auxin pathway (Brady et al. 2003; Rock and Sun 2005; Thole et al. 2014; Ren and Wang 2016; Li et al. 2017; Shuai et al. 2017). The sensitivity to auxin correlates with the sensitivity to ABA (Thole et al. 2014). Although the auxin is considered the primary hormone regulating root meristem function, $\mathrm{ABA}$ also has shown to modulate the major control points of root growth: regulate root meristem function, modulate root length and lateral root development (Harris 2015). ABA plays a positive role in the stimulation of lateral roots (Harris 2015) inducing expression of ABI3 (Brady et al. 2003; Smet et al. 2006).

\section{Expression of CaVAL2 is increased in late stage of the somatic embryo}

To our knowledge, the functional characterization of the VAL genes was performed only on zygotic embryogenesis. During this embryogenesis process, $V A L$ genes are involved in the role of repressing the AFL network during germination for seedling growth to occur normally (Suzuki et al. 2007; Sharma et al. 2013; Jia et al. 2014) although the VAL genes are also expressed in many tissues (Tsukagoshi 2005). A result shows that $V A L$ 's member has the potential to regulate gene expression at both the epigenetic and transcriptional level (Schneider et al. 2016).

Our results showed that expression of CaVAL2 was upregulated expression in plantlets and cotyledonary embryos, this expression profile in C. arabica was not described by any other study. The genes regulated during later stages of somatic embryogenesis may serve as developmental markers for improving the regeneration (Che et al. 2006; EnríquezValencia et al. 2019). Based on the high expression in the later stage embryos, the CaVAL2 gene can contribute for selection of good material in bioreactor production of clonal coffee. CaVAL2 can play an essential role in regulating the transition from embryo maturation to plantlets growth. Corroborating, VAL1/VAL2 double mutants of Arabidopsis show irregular development of cotyledons and radicle (Tsukagoshi et al. 2007).

Based on our results, VAL2 does not seem to repress $A B I 3$ targets, the high expression of VAL2 occurred at a stage of the somatic embryo following the low $A B I 3$ transcript. Schneider et al. (2016) concluded that VAL1 in Arabidopsis seems to repress FUS3 targets in particular, and to some extent those of $L E C 1$ and $L E C 2$, but not $A B I 3$ targets.

This study identifies and observes the expression of probable orthologs of $A B I 3$ and VAL2 during the whole process of somatic embryogenesis in C. arabica integrated with histological analysis and regeneration rates. Histological analysis from embryogenic cell suspensions allowed the identification of proembryogenic and non-embryogenic masses in all months in vitro culture. The activity of $C a A B I 3$ is correlated to embryogenic potential with highly expressed in embryogenic masses and expression of the VAL2 gene is increased at the end of the embryogenic process. Furthermore, the rate of regeneration of somatic embryos from cell suspensions increased in relation to the culture time. The results presented here may help to elucidate the embryos induction process and facilitate the development of efficient coffee plant regeneration procedures.

Acknowledgements This research was supported by Fundação de Amparo à Pesquisa de Minas Gerais (FAPEMIG), Coordenação de Aperfeiçoamento de Pessoal de Nível Superior (CAPES) and Conselho Nacional de Desenvolvimento Científico e Tecnológico (CNPq). These funding programs had no participation in study design, data collection and analysis, decision to publish, or preparation of the manuscript.

Author contributions NCF, HGB and LVP conceived and designed the experiments; NCF, HGB, LFT, LLF, LAZR and LZB performed the experiments and analysed the data; NCF, LVP, LZB and LECD interpreted the data; NCF wrote the paper; LVP, LECD and LFT revised the paper, all authors had read and approved the final manuscript.

\section{Compliance with ethical standards}

Conflict of interest The authors declare that they have no conflict of interest.

\section{References}

Abbasi BH, Ali H, Yücesan B, Saeed S, Rehman K, Khan MA (2016) Evaluation of biochemical markers during somatic embryogenesis in Silybum marianum L. 3 Biotech 6:71

Ahmad I, Johansson S, Andrade G, Dedicova B, Egertsdotter U (2011) Somatic embryogenesis for mass propagation of elite Spruce families: effect of storage time on somatic embryogenesis initiation. BMC Proc 5:P127 
Anandan R, Sudhakar D, Balasubramanian P, Gutiérrez-Mora A (2012) In vitro somatic embryogenesis from suspension cultures of $\mathrm{Car}$ ica papaya L. Sci Hortic 136:43-49

Ascencio-Cabral A, Gutiérrez-Pulido H, Rodríguez-Garay B, Gutiérrez-Mora A (2008) Plant regeneration of Carica papaya L. through somatic embryogenesis in response to light quality, gelling agent and phloridzin. Sci Hortic 118:155-160

Barampuram S, Zhang ZJ (2011) Recent advances in plant transformation. In: Birchler JA (ed) Plant chromosome engineering: methods and protocols, methods in molecular biology, vol 701. Humana Press, Totowa, pp 1-35

Bartos PMC, Gomes HT, Gomes SM, Vasconcelos Filho SC, Teixeira JB, Scherwinski-Pereira JE (2018) Histology of somatic embryogenesis in Coffea arabica L. Biologia 73(12):1255-1265

Beena MR, Winter S, Makeshkumar T (2014) Influence of age of explants and genotype on somatic embryogenesis in African and Indian cassava cultivars. J Root Crops 40:21-27

Brady SM, Sarkar SF, Bonetta D, McCourt P (2003) The ABSCISIC ACID INSENSITIVE 3 (ABI3) gene is modulated by farnesylation and is involved in auxin signaling and lateral root development in Arabidopsis. Plant J 34(1):67-75

Campos NA, Panis B, Carpentier SC (2017) Somatic embryogenesis in coffee: the evolution of biotechnology and the integration of omics technologies offer great opportunities. Front Plant Sci $8: 1460$

Carbonero P, Iglesias-Fernández R, Vicente-Carbajosa J (2017) The AFL subfamily of B3 transcription factors: evolution and function in angiosperm seeds. J Exp Bot 68:871-880

Castillejo C, Pelaz S (2008) The balance between CONSTANS and TEMPRANILLO activities determines FT expression to trigger flowering. Curr Biol 18:1338-1343

Che P, Love TM, Frame BR, Wang K, Carriquiry AL, Howell SH (2006) Gene expression patterns during somatic embryo development and germination in maize Hi II callus cultures. Plant Mol Biol 62:1-14

Cloutier S, Landry BS, De Recherches S, Canada A (1994) Review molecular markers applied to plant tissue culture. In Vitro Cell Dev Biol 30:32-39

de Carvalho CHS (2007) Cultivares de café. EMBRAPA, Brasília, p 247

de Rezende Maciel AL, Rodrigues FA, Pasqual M, de Carvalho CHS (2016) Large-scale, high-efficiency production of coffee somatic embryos. Crop Breed Appl Biotechnol 16:102-107

de Smet I, Zhang H, Inzé D, Beeckman T (2006) A novel role for abscisic acid emerges from underground. Trends Plant Sci 11(9):434-439

Delporte F, Muhovski Y, Pretova A, Watillon B (2013) Analysis of expression profiles of selected genes associated with the regenerative property and the receptivity to gene transfer during somatic embryogenesis in Triticum aestivum L. Mol Biol Rep 40:5883-5906

Enríquez-Valencia AJ, Vázquez-Flota FA, Ku-Cauich JR, EscobedoGraciaMedran RM (2019) Differentially expressed genes during the transition from early to late development phases in somatic embryo of banana (Musa spp. AAB group, Silk subgroup) cv. Manzano. Plant Cell Tissue Organ Cult 136(2):289-302

Farzana A, Palkadapala P, Meddegoda K, Samarajeewa P, Eeswara J (2008) Somatic embryogenesis in papaya (Carica papaya L.) cv. Rathna. J Natl Sci Found Sri Lanka 36:41-50

Florez SL, Erwin RL, Maximova SN, Guiltinan MJ, Curtis WR (2015) Enhanced somatic embryogenesis in Theobroma cacao using the homologous BABY BOOM transcription factor. BMC Plant Biol 15:1-13

Fraga HP, Vieira LD, Puttkammer CC, Dos Santos HP, Garighan JA, Guerra MP (2016) Glutathione and abscisic acid supplementation influences somatic embryo maturation and hormone endogenous levels during somatic embryogenesis in Podocarpus lambertii Klotzsch ex Endl. Plant Sci 253:98-106

Freitas NC, Barreto HG, Fernandes-Brum CN, Moreira RO, ChalfunJunior A, Paiva LV (2017) Validation of reference genes for qPCR analysis of Coffea arabica L. somatic embryogenesisrelated tissues. Plant Cell Tissue Organ Cult 128:663-678

Gaj MD, Zhang S, Harada JJ, Lemaux PG (2005) Leafy cotyledon genes are essential for induction of somatic embryogenesis of Arabidopsis. Planta 222:977-988

Gao Y, Liu J, Zhang Z et al (2013) Functional characterization of two alternatively spliced transcripts of tomato ABSCISIC ACID INSENSITIVE3 (ABI3) gene. Plant Mol Biol 82:131-145

Gatica AM, Arrieta G, Espinoza AM (2007) Comparison of three in vitro protocols for direct somatic embryogenesis and plant regeneration of Coffea arabica L. cvs. Caturra e Catuaí. Agronomía Costarricense 31:85-94

Gawronska H, Burza W, Bolesta E, Malepszy S (2000) Zygotic and somatic embryos of cucumber (Cucumis sativus L.) substantially differ in their levels of abscisic acid. Plant Sci 157:129-137

Golovko A (2001) Genetic variability of somatic embryogenesis in tissue cultures of sugar beet breeding lines. TSitologiia I Genetika 35:10-17

Gruszczyńska A, Rakoczy-Trojanowska M (2011) Expression analysis of somatic embryogenesis-related SERK, LEC1, VP1 and NiR ortologues in rye (Secale cereale L.). J Appl Genet 52:1-8

Guan Y, Li S-G, Fan X-F, Su Z-H (2016) Application of somatic embryogenesis in woody plants. Front Plant Sci 7:1-12

Harris JM (2015) Abscisic acid: hidden architect of root system structure. Plants 4(3):548-572

Hu YX, Wang YH, Liu XF, Li JY (2004) Arabidopsis RAV1 is downregulated by brassinosteroid and may act as a negative regulator during plant development. Cell Res 14:8-15

Ikeda Y, Banno H, Niu QW, Howell SH, Chua NH (2006) The ENHANCER OF SHOOT REGENERATION 2 gene in Arabidopsis regulates CUP-SHAPED COTYLEDON 1 at the transcriptional level and controls cotyledon development. Plant Cell Physiol 47:1443-1456

Ikeda-Iwai M, Satoh S, Kamada H (2002) Establishment of a reproducible tissue culture system for the induction of Arabidopsis somatic embryos. J Exp Bot 53:1575-1580

Ikeda-Iwai M, Umehara M, Satoh S, Kamada H (2003) Stress-induced somatic embryogenesis in vegetative tissues of Arabidopsis thaliana. Plant J 34:107-114

Jia H, McCarty DR, Suzuki M (2013) Distinct roles of LAFL network genes in promoting the embryonic seedling fate in the absence of VAL repression. Plant Physiol 163:1293-1305

Jia H, Suzuki M, Mccarty DR (2014) Regulation of the seed to seedling developmental phase transition by the LAFL and VAL transcription factor networks. Wiley Interdiscip Rev: Dev Biol 3:135-145

Jiménez VM (2001) Regulation of in vitro somatic embryogenesis with emphasis on to the role of endogenous hormones. Revista Brasileira de Fisiologia Vegetal 13:196-223

Jonsson K, Boutté Y, Singh RK, Gendre D, Bhalerao R (2017) Ethylene regulates differential growth via BIG ARF-GEF-dependent post-Golgi secretory trafficking in Arabidopsis. Plant Cell 29:1039-1052

Kamada H, Harada H (1979) Studies on the organogenesis in carrot tissue cultures. I. Effects of growth regulators on somatic embryogenesis and root formation. Zeitschrift für Pflanzenphysiologie 91:255-266

Karami O, Aghavaisi B, Pour AM (2009) Molecular aspects of somaticto-embryogenic transition in plants. J Chem Biol 2(4):177-190

Kikuchi A, Sanuki N, Higashi K, Koshiba T, Kamada H (2006) Abscisic acid and stress treatment are essential for the acquisition of embryogenic competence by carrot somatic cells. Planta 223:637-645 
Kumar S, Stecher G, Tamura K (2016) MEGA7: molecular evolutionary genetics analysis version 7.0 for bigger datasets. Mol Biol Evol 33:1870-1874

Ledwoń A, Gaj MD (2009) LEAFY COTYLEDON2 gene expression and auxin treatment in relation to embryogenic capacity of Arabidopsis somatic cells. Plant Cell Rep 28:1677-1688

Li SB, Xie ZZ, Hu CG, Zhang JZ (2016) A review of auxin response factors (ARFs) in plants. Front Plant Sci 7:47

Li X, Chen L, Forde BG, Davies WJ (2017) The biphasic root growth response to abscisic acid in arabidopsis involves interaction with ethylene and auxin signalling pathways. Front Plant Sci 8:1493

Loyola-Vargas VM, Fuentes-Cerda CFJ, Monforte-Gonzales M, Mendez-Zeel M, Rojas-Herrera R, Mijangos-Cortes J (1999) Coffee tissue culture as a new model for the study of somaclonal variation. In: Proceedings of the 18th ASIC Colloquium (Helsinki), pp. 302-307. ASIC, Paris, France

Ma J, He Y, Hu Z, Xu W, Xia J, Guo C, Lin S, Chen C, Wu C, Zhang $J$ (2014) Characterization of the third SERK gene in pineapple (Ananas comosus) and analysis of its expression and autophosphorylation activity in vitro. Genet Mol Biol 37:530-539

Mahdavi-Darvari F, Noor NM, Ismanizan I (2015) Epigenetic regulation and gene markers as signals of early somatic embryogenesis. Plant Cell Tissue Organ Cult 120:407-422

Malabadi RB, Kumar SV, Mulgund GS, Nataraja K (2011) Induction of somatic embryogenesis in Papaya (Carica papaya). Res Biotechnol 2(5):40-55

Martins JF, Correia SI, Canhoto JM (2016) Somatic embryogenesis induction and plant regeneration in strawberry tree (Arbutus unedo L.). In: Germana M, Lambardi M (eds) In vitro embryogenesis in higher plants. Methods in molecular biology, vol 1359. Humana Press, New York

Maślanka M, Janowiak ABF (2016) Endogenous ABA content in relation to maturation of somatic embryos in Tulipa (L.) 'Apeldoorn' cultures. Acta Physiol Plant 38:270

Matías-Hernández L, Aguilar-Jaramillo AE, Marín-González E, Suárez-López P, Pelaz S (2014) RAV genes: regulation of floral induction and beyond. Ann Bot 114:1459-1470

Mazarei M, Al-Ahmad H, Rudis MR, Joyce BL, Stewart CN (2011) Switchgrass (Panicum virgatum L.) cell suspension cultures: establishment, characterization, and application. Plant Sci 181:712-715

Nagpal P, Ellis CM, Weber H et al (2005) Auxin response factors ARF6 and ARF8 promote jasmonic acid production and flower maturation. Development 132:4107-4118

Nakashima K, Fujita Y, Katsura K et al (2006) Transcriptional regulation of ABI3- and ABA-responsive genes including RD29B and RD29A in seeds, germinating embryos, and seedlings of Arabidopsis. Plant Mol Biol 60:51-68

Nic-Can GI, López-Torres A, Barredo-Pool F, Wrobel K, LoyolaVargas VM, Rojas-Herrera R et al (2013) New insights into somatic embryogenesis: leafy cotyledon 1 , baby boom 1 and WUSCHEL-related homeobox 4 are epigenetically regulated in Coffea canephora. PLoS ONE 8(8): 72160

Normah M, Rohani E, Mohamed-Hussein Z (2013) Somatic embryogenesis in higher plants. Malays Appl Biol J 42(2):1-12

O'Brien TP, Feder N, McCully ME (1964) Polychromatic staining of plant cell walls by toluidine blue O. Protoplasma 59:368-373

Pfaffl MW (2001) A new mathematical model for relative quantification in real-time RT-PCR. Nucleic Acids Res 29:e45

Pinto DLP, de Almeida AMR, Rêgo MM, da Silva ML, de Oliveira EJ, Otoni WC (2011) Somatic embryogenesis from mature zygotic embryos of commercial passionfruit (Passiflora edulis Sims) genotypes. Plant Cell Tissue Organ Cult 107: 521-530

Quiroz-Figueroa FR, Fuentes-Cerda CFJ, Rojasherrera R, LoyolaVargas VM (2002) Histological studies on the developmental stages and differentiation of two different somatic embryogenesis systems of Coffea arabica. Plant Cell Rep 20:1141-1149

Quiroz-Figueroa FR, Rojas-Herrera R, Galaz-Avalos RM, Loyola-Vargas VM (2006) Embryo production through somatic embryogenesis can be used to study cell differentiation in plants. Plant Cell Tissue Organ Cult 86:285-301

R Development Core Team (2008) Version 2.6.2: R: a language and environment for statistical computing. R Foundation for Statistical Computing, Vienna

Radoeva T, Weijers D (2014) A roadmap to embryo identity in plants. Trends Plant Sci 19:709-716

Raja NI, Bano A, Rashid H, Khan MH, Chaudhry Z (2009) Efeect of age of embryogenic callus on plant regeneration in local cultivars of wheat (Triticum aestivum L.). Pak J Bot 41(6):2801-2806

Ren Z, Wang X (2016) SITIR1 is involved in crosstalk of phytohormones, regulates auxin-induced root growth and stimulates stenospermocarpic fruit formation in tomato. Plant Sci 253:13-20

Rezende JCD, Carvalho CHSD, Pasqual M, Santos ACR, Carvalho SMD (2011) Calli induction in leaf explants of coffee elite genotypes. Ciência Rural 41(3):384-389

Ribas AF, Dechamp E, Champion A et al (2011) Agrobacteriummediated genetic transformation of Coffea arabica (L.) is greatly enhanced by using established embryogenic callus cultures. BMC Plant Biol 11:92

Rocha DI, Pinto DLP, Vieira LM et al (2016) Cellular and molecular changes associated with competence acquisition during passion fruit somatic embryogenesis: ultrastructural characterization and analysis of SERK gene expression. Protoplasma 253:595

Rock CD, Sun X (2005) Crosstalk between ABA and auxin signaling pathways in roots of Arabidopsis thaliana (L.) Heynh. Planta 222(1):98-106

Romanel EAC, Schrago CG, Counãgo RM, Russo CAM, Alves-Ferreira M (2009) Evolution of the B3 DNA binding superfamily: new insights into REM family gene diversification. PLoS ONE 4(6):e5791

Saitou N, Nei M (1987) The neighbor-joining method: a new method for reconstructing phylogenetic trees. Mol Biol Evol 4:406-425

Sané D, Aberlenc-Bertossi F, Diatta LID et al (2012) Influence of growth regulators on callogenesis and somatic embryo development in date palm (Phoenix dactylifera L.) Sahelian cultivars. Sci World J 2012:1-8

Savita, Singh B, Virk GS, Nagpal AK (2011) An efficient plant regeneration protocol from callus cultures of Citrus jambhiri Lush. Physiol Mol Biol Plants 17:161-169

Savona M, Mattioli R, Nigro S, Falasca G, Della Rovere F, Costantino P, De Vries S, Ruffoni B, Trovato M, Altamura MM (2012) Two SERK genes are markers of pluripotency in Cyclamen persicum Mill. J Exp Bot 63:471-488

Schneider A, Aghamirzaie D, Elmarakeby H et al (2016) Potential targets of VIVIPAROUS1/ABI3-LIKE1 (VAL1) repression in developing Arabidopsis thaliana. Plant J 85:305-319

Sharma N, Bender Y, Boyle K, Fobert PR (2013) High-level expression of sugar inducible gene2 (HSI2) is a negative regulator of drought stress tolerance in Arabidopsis. BMC Plant Biol 13:170

Shiota H, Satoh R, Watabe K, Harada H, Kamada H (1998) C-ABI3, the carrot homologue of the Arabidopsis ABI3, is expressed during both zygotic and somatic embryogenesis and functions in the regulation of embryo-specific ABA-inducible genes. Plant Cell Physiol 39:1184-1193

Shivani AP, Sharma V, Kaur N, Kaur N, Pandey P et al (2017) Genome-wide analysis of transcription factors during somatic embryogenesis in banana (Musa spp.) cv. Grand Naine. PLoS ONE 12(8): 0182242

Shuai H, Meng Y, Luo X et al (2017) Exogenous auxin represses soybean seed germination through decreasing the gibberellin/abscisic acid (GA/ABA) ratio. Sci Rep 7:12620 
Silva AT, Barduche D, do Livramento KG, Ligterink W, Paiva LV (2014) Characterization of a putative serk-like ortholog in embryogenic cell suspension cultures of Coffea arabica L. Plant Mol Biol Rep 32:176-184

Silva AT, Barduche D, do Livramento KG, Paiva LV (2015) A putative BABY BOOM-like gene (CaBBM) is expressed in embryogenic calli and embryogenic cell suspension culture of Coffea arabica L. In Vitro Cell Dev Biol—Plant 51:93-101

Simões C, Albarello N, Callado CH, de Castro TC, Mansur E (2010) Somatic embryogenesis and pant regeneration from callus cultures of Cleome rosea Vahl. Braz Arch Biol Technol 53:679-686

Singh RK, Ruiz-May E, García-Pérez LM, Quiroz-Figueroa FR (2016) Somatic embryogenesis in Jatropha curcas. In: Loyola-Vargas VM, Ochoa-Alejo N (eds) Somatic embryogenesis: fundamental aspects and applications. Springer, Cham, pp 401-412

Sitnikova T, Rzhetsky A, Nei M (1995) Interior-branch and bootstrap tests of phylogenetics trees. Mol Biol Evol 12:319-333

Stone SL, Kwong LW, Yee KM et al (2001) LEAFY COTYLEDON2 encodes a B3 domain transcription factor that induces embryo development. Proc Natl Acad Sci USA 98:11806-11811

Sun DQ, Lu XH, Liang GL, Guo QG, Mo YW, Xie JH (2011) Production of triploid plants of papaya by endosperm culture. Plant Cell Tissue Organ Cult 104:23-29

Suzuki M, McCarty DR (2008) Functional symmetry of the B3 network controlling seed development. Curr Opin Plant Biol 11:548-553

Suzuki M, Wang HH-Y, McCarty DR (2007) Repression of the LEAFY COTYLEDON 1/B3 regulatory network in plant embryo development by VP1/ABSCISIC ACID INSENSITIVE 3-LIKE B3 genes. Plant Physiol 143:902-911

Swaminathan K, Peterson K, Jack T (2008) The plant B3 superfamily. Trends Plant Sci 13:647-655

Teixeira JB, Junqueira CS, Pereira AJPC, Mello RISD, Silva APDD, Mundim DA (2004) Multiplicação clonal de café (Coffea arabica L.) via embriogênese somática. Embrapa Documentos 121:39

Thole JM, Beisner ER, Liu J, Venkova SV, Strader LC (2014) Abscisic acid regulates root elongation through the activities of auxin and ethylene in Arabidopsis thaliana. G3: Genes Genomes Genet 4(7): 1259-1274

Thompson JD, Higgins DG, Gibson TJ (1994) Improving the sensitivity of progressive multiple sequence alignment through sequence weighting, position-specific gap penalties and weight matrix choice. Nucleic Acids Res 22:4673-4680
Torres LF, Diniz LEC, Do Livramento KG, Freire LL, Paiva LV (2015) Gene expression and morphological characterization of cell suspensions of Coffea arabica L. cv. Catiguá MG2 in different cultivation stages. Acta Physiol Plant 37:175

Tsukagoshi H (2005) Analysis of a sugar response mutant of Arabidopsis identified a novel B3 domain protein that functions as an active transcriptional repressor. Plant Physiol 138:675-685

Tsukagoshi H, Morikami A, Nakamura K (2007) Two B3 domain transcriptional repressors prevent sugar-inducible expression of seed maturation genes in Arabidopsis seedlings. Proc Natl Acad Sci 104:2543-2547

Van Boxtel J, Berthouly M (1996) High frequency somatic embryogenesis from coffee leaves. Factors influencing embryogenesis and subsequent proliferation and regeneration in liquid medium. Plant Cell Tissue Organ Cult 44:4-17

Verma SK, Das AK, Cingoz GS, Uslu E, Gurel E (2016) Influence of nutrient media on callus induction, somatic embryogenesis and plant regeneration in selected Turkish crocus species. Biotechnol Rep 10:66-74

Vieira LGE, Andrade AC, Colombo CA (2006) Brazilian coffee genome project: an EST-based genomic resource. Braz J Plant Physiol 18:95-108

Wójcikowska B, Gaj MD (2017) Expression profiling of AUXIN RESPONSE FACTOR genes during somatic embryogenesis induction in Arabidopsis. Plant Cell Rep 36:843-858

Zamarripa A, Ducos JP, Bollon H, Dufour M, Pétiard V (1991) Production d'embryons somatiques de caféier en milieu liquide: effets densité d'inoculation et renouvellement du milieu. Café Cacao Thé 35:233-244

Zhang Y, Clemens A, Maximova SN, Guiltinan MJ (2014) The Theobroma cacao B3 domain transcription factor TcLEC2 plays a duel role in control of embryo development and maturation. BMC Plant Biol 14:1-16

Zhao L, Luo Q, Yang C, Han Y, Li W (2008) A RAV-like transcription factor controls photosynthesis and senescence in soybean. Planta 227:1389-1399

Publisher's Note Springer Nature remains neutral with regard to jurisdictional claims in published maps and institutional affiliations.

\section{Affiliations}

\section{Natália Chagas Freitas ${ }^{1} \cdot$ Horllys Gomes Barreto ${ }^{2}$. Luana Ferreira Torres ${ }^{1} \cdot$ Luciana Lima Freire $^{1}$. Leonardo Augusto Zebral Rodrigues ${ }^{1}$ - Leandro Eugenio Cardamone Diniz ${ }^{3}$. Luiz Alberto Beijo ${ }^{4}$. Luciano Vilela Paiva' ${ }^{1}$ (1)}

1 Central Laboratory of Molecular Biology, Department of Chemistry, Federal University of Lavras, Lavras, Minas Gerais, Brazil

2 Molecular Analyzes Laboratory, Business Incubator HABITE, Federal University of Tocantins, Palmas, Tocantins, Brazil
3 Brazilian Agricultural Research Corporation, Embrapa Tabuleiros Costeiros, Aracaju, Sergipe, Brazil

4 Department of Statistics, Federal University of Alfenas, Alfenas, Minas Gerais, Brazil 